\title{
КОНТИНЕНТАЛЬНАЯ КОРА В ЗАПАДНОЙ ЧАСТИ АМЕРАЗИЙСКОГО БАССЕЙНА. МЕХАНИЗМЫ ПОГРУЖЕНИЯ
}

Артюшков Е. В., Смирнов О. Е., Чехович П. А.

\begin{abstract}
Аннотация
В западной части Амеразийского бассейна Северного Ледовитого океана расположены котловины Подводников и Макарова. Анализ данных о строении их осадочного чехла и истории развития погружения земной коры показывает, что, несмотря на большие глубины воды (3-4 км), эти структуры подстилаются корой континентального типа. До образования глубоководных впадин в миоцене поверхность земной коры располагалась здесь вблизи уровня моря. Растяжение внесло лишь небольшой вклад в ее крупное погружение. Его основной причиной был переход габбро в нижней части континентальной коры в более плотные эклогиты. Из-за того, что скорости продольных волн в эклогитах и в мантийных перидотитах почти одинаковы, при построении сейсмогравитационных моделей глубоководных котловин высокоскоростные эклогиты основного состава относят к мантийной части литосферы, помещая их под разделом Мохо. Расположенная выше часть коры в котловине Подводников рассматривается как утоненная континентальная кора, а в котловине Макарова - как кора океанического типа. Предложенный механизм погружения позволяет изменить модель строения коры и трактовать высокоскоростные эклогиты как нижнюю часть континентальной коры, испытавшей проградный метаморфизм под воздействием мантийных флюидов.
\end{abstract}

\section{Ключевые слова:}

Сверхглубокие осадочные бассейны, аномалии силы тяжести, изостатическое равновесие, сейсмическое профилирование МОВ-ОГТ, растяжение коры, эклогитизация, раздел Мохо, Амеразийский бассейн, котловина Подводников. 


\title{
КОНТИНЕНТАЛЬНАЯ КОРА В ЗАПАДНОЙ ЧАСТИ АМЕРАЗИЙСКОГО БАССЕЙНА. МЕХАНИЗМЫ ПОГРУЖЕНИЯ
}

\author{
Е.В. Артюшков ${ }^{1}$, О.Е. Смирнов ${ }^{2}$, П.А. Чехович ${ }^{1,3}$
}

\begin{abstract}
${ }^{1}$ Институт физики Земли им. О.Ю. Шмидта РАН (ИФЗ РАН), 123995, Москва, ул. Б. Грузинская 10 ${ }^{2}$ ФББУ "ВНИИОкеангеология", 190121, Санкт-Петербург, Английский проспект, д. 1

${ }^{3}$ МГУ имени М.В. Ломоносова, Музей землеведения, 119991, Москва, ГСП-1, Ленинские горы
\end{abstract}

В западной части Амеразийского бассейна Северного Ледовитого океана расположены котловины Подводников и Макарова. Анализ данных о строении их осадочного чехла и истории развития погружения земной коры показывает, что, несмотря на большие глубины воды (3-4 км), эти структуры подстилаются корой континентального типа. До образования глубоководных впадин в миоцене поверхность земной коры располагалась здесь вблизи уровня моря. Растяжение внесло лишь небольшой вклад в ее крупное погружение. Его основной причиной был переход габбро в нижней части континентальной коры в более плотные эклогиты. Из-за того, что скорости продольных волн в эклогитах и в мантийных перидотитах почти одинаковы, при построении сейсмогравитационных моделей глубоководных котловин высокоскоростные эклогиты основного состава относят к мантийной части литосферы, помещая их под разделом Мохо. Расположенная выше часть коры в котловине Подводников рассматривается как утоненная континентальная кора, а в котловине Макарова - как кора океанического типа. Предложенный механизм погружения позволяет изменить модель строения коры и трактовать высокоскоростные эклогиты как нижнюю часть континентальной коры, испытавшей проградный метаморфизм под воздействием мантийных флюидов.

Сверхглубокие осадочные бассейны, аномалии силы тяжести, изостатическое равновесие, сейсмическое профилирование МОВ-ОГТ, растяжение коры, эклогитизация, раздел Мохо, Амеразийский бассейн, котловина Подводников.

\section{THE CONTINENTAL CRUST BENEATH THE WESTERN AMERASIAN BASIN. MECHANISMS OF CRUSTAL SUBSIDENCE}

\section{E.V. Artyushkov, O.E. Smirnov, P.A. Chekhovich}

The western part of a wide Amerasian Basin in Arctic Ocean includes two minor basins: the Podvodnikov and Makarov ones. The analysis of the data on the sedimentary cover structure and crustal subsidence history suggests that despite a large depth of water, up to 3-4 km, both basins are underlain by continental crust. Before the rapid formation of deep-water basins in the Early Miocene, the crustal surface for a long time remained near to sea level. Lithospheric stretching has made only a minor input into the crustal subsidence. The main cause of the subsidence was prograde metamorphism in the lower continental crust with the transformation of gabbroids to denser eclogite type rocks. The $P$-wave velocities in eclogites and mantle peridotites are rather similar. Hence, in interpreting the seismic data, high-velocity eclogites are commonly considered as the uppermost part of the mantle located below the Moho, while the overlying rocks are shown as the attenuated continental crust in the Podvodnikov Basin and the oceanic crust in the Makarov Basin. The proposed mechanism makes it possible to modify the model of crustal structure and to interpret high-velocity eclogites as lower part of the continental crust that has undergone a prograde metamorphism under the influence of mantle fluids. 
Ultradeep basins, gravity anomalies, isostatic equilibrium, CDP seismic reflection survey, crustal stretching, eclogitization, Mohorovicic discontinuity, Amerasian Basin, Podvodnikov Basin.

\section{ВВЕДЕНИЕ}

В Центральной Арктике расположена система крупных глубоководных прогибов (рис. 1). В ее западной части - в Евразийском бассейне преобладает океаническая кора, сформировавшаяся за последние 53 млн. лет в результате спрединга на хребте Гаккеля. К востоку от Евразийского бассейна расположен Амеразийский бассейн. С помощью глубоководного бурения существование в нем континентальной коры было надежно установлено только для хребта Ломоносова на западной окраине бассейна [Moran et al., 2006; Backman et al., 2006] на основе наличия в разрезе остатков мелководной фауны и субаэральных перерывов в осадконакоплении. Далее к востоку - в котловинах Подводников и Макарова, на подводном поднятии Альфа-Менделеева и в Канадской котловине природа коры остается дискуссионной. Ряд авторов считает, что основную часть площади в этих областях занимает кора океанического типа [Lawver et al., 2002; Grantz et al., 2011; Mooney, 2007; Dore et. al, 2015 и другие]. Другая точка зрения, которой придерживаются многие российские исследователи, предполагает, что под котловиной Подводников, а также под поднятием Альфа-Менделеева залегает континентальная кора [Petrov et. al, 2016; Пискарев и др., 2017; Дараган-Сущова и др., 2017; Кашубин и др., 2018; Поселов и др., 2019]. Еще одна группа исследователей в своих публикациях осторожно обходят вопрос о типе коры в котловине Подводников [Nikishin et al., 2017; Jokat et al., 2013]. Кору в котловине Макарова чаще относят к океаническому типу (там же).

Такое разнообразие точек зрений на природу коры в Амеразийском бассейне объясняется, прежде всего, неравномерностью его геолого-геофизической изученности. Основным предметом исследований во многих публикациях являются отдельные относительно небольшие тектонические элементы шельфа или глубоководья, и сделанные по ним конкретные научные заключения экстраполируются далеко за их пределы со ссылкой на ту или иную геодинамическую концепцию. При этом, предлагаемые глубинные механизмы тектонических процессов, остаются не подтвержденными численными расчётами с использованием петрофизических характеристик литосферы.

За последние 5-10 лет в Амеразийском бассейне российскими и зарубежными организациями получено большое количество высококачественных сейсмических материалов МОВ-ОГТ, которые позволили на новом уровне выполнить структурные построения с учётом имеющихся данных о возрастной привязке отражающих горизонтов в осадочном чехле. Указанные материалы в сочетании с анализом глубинного строения осадочных бассейнов с большой мощностью осадочного чехла в других регионах легли в основу разработанного в данной статье механизма погружения.

\section{НЕКОТОРЫЕ ОСОБЕННОСТИ СТРОЕНИЯ ЗЕМНОЙ КОРЫ В ЗАПАДНОЙ ЧАСТИ БАССЕЙНА}

Основным доводом в пользу существования океанической коры в Амеразийском бассейне послужили вначале его батиметрические характеристики - диапазон глубин меняется здесь в пределах 1-4 км [Lowver et al., 2002 и др.]. Этот аргумент, однако, нельзя признать убедительным. Для ряда осадочных бассейнов на континентах характерна высокая мощность осадочного чехла. Снятие нагрузки слоя осадков с плотностью рос и

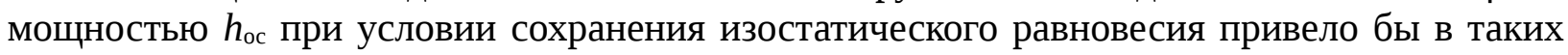
бассейнах к образованию впадины с глубиной воды

$$
h_{\mathrm{B}}=\left[\left(\rho_{\mathrm{M}}-\rho_{\mathrm{oc}}\right) /\left(\rho_{\mathrm{M}}-\rho_{\mathrm{B}}\right)\right] h_{\mathrm{oc}},
$$




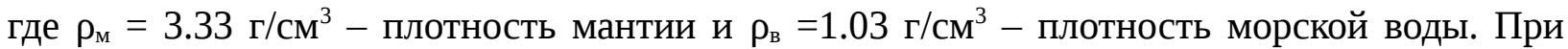

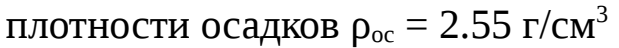

$$
h_{\mathrm{B}}=0.34 h_{\mathrm{oc}},
$$

Так, для Вилюйской синеклизы со средней мощностью осадков в ее центральной части $h_{\text {ос }}$ $=10-12$ км, из (2) получаем $h_{\text {в }}=3.4-4.1$ км. В Прикаспийской впадине на докембрийской коре после снятия с нее 20 км осадков [Артюшков, Егоркин, 2005] глубина воды достигла бы 6.8 км. Поэтому сами по себе батиметрические уровни дна 1-4 км в котловинах Подводников и Макарова, не могут рассматриваться как свидетельство существования под ними коры океанического типа.

Для океанической коры, образовавшейся на оси спрединга, характерны системы полосовых магнитных аномалий с чередующейся полярностью. В Амеразийском бассейне ясно выраженные аномалии такого типа отсутствуют. Это пытаются объяснить формированием в нем океанической коры в эпоху мелового суперхрона 83-125 млн. лет назад [Olson, Amit, 2015], когда магнитное поле Земли сохраняло положительную полярность. По своим свойствам кора в Амеразийском бассейне сильно отличается от типичной океанической коры. Мощность последней в среднем равна 7 км, и в большинстве областей она плавно изменяется на площади. В Амеразийском бассейне на основной части площади мощность коры составляет 10-20 км и более. Кроме того, она изменяется от 8-12 км в котловине Макарова до 25-30 км на поднятии Менделеева. Повышенную мощность коры в указанных областях объясняют андерплейтингом и внедрением в кору базальтовых интрузий в Большой магматической провинции Высокоширотной Арктики (HALIP) [Oakey, Saltus, 2016; Evangelatos et al., 2017 и др.].

В пользу существования в рассматриваемой области океанической коры могут свидетельствовать высокие средние скорости продольных волн, типичные для земной коры под океанами. Однако, как показывают глубинные сейсмические зондирования, в верхней части консолидированной коры котловин Подводников и Макарова, а также поднятия Альфа-Менделеева, существует слой толщиной 1-5 км, а местами и более со скоростями продольных волн, характерными для гранитного слоя континентальной коры [Кашубин и др., 2018]. Поэтому большинство российских ученых предполагают, что эти структуры подстилаются корой континентального типа [Пискарев и др., 2017]. В таком случае возникает, однако, вопрос, с чем были связаны крупные погружения, сформировавшие глубоководные впадины на континентальной коре, обычно располагающейся вблизи уровня моря или выше этого уровня.

Образование глубоководных впадин на континентальной коре в указанных областях российские ученые обычно связывают с ее растяжением, о котором свидетельствует существование сбросов в фундаменте осадочных бассейнов [Nikishin et al., 2017 и др.]. Обычно такое заключение делается на качественном уровне без оценки интенсивности растяжения, необходимого для обеспечения наблюдаемого погружения. На основе анализа геофизических данных ранее было показано [Артюшков и др., 2014], что в таких сверхглубоких прогибах, как Северо-Баренцевский, Прикаспийский и в некоторых других, растяжение было ответственным лишь за небольшую часть наблюдаемого погружения коры. Точно так же, существенным растяжением не сопровождалось и погружение, сформировавшее в неогене глубоководный бассейн на хребте Ломоносова, располагавшемся до этого вблизи уровня моря [Artyushkov, Chekhovich, 2019]. Как и для указанных выше сверхглубоких прогибов, можно предположить, что основной вклад в погружение был обусловлен уплотнением пород земной коры вследствие метаморфизма, сопровождавшегося существенным повышением скоростей продольных волн. В таком случае высокие скорости продольных волн под Амеразийским бассейном, если бы они и были зафиксированы, еще не являлись бы доказательством океанической природы коры. 
В этой работе мы рассматриваем сейсмические и гравиметрические данные по котловинам Подводников и Макарова в западной части Амеразийского бассейна. Основные задачи - определить природу земной коры в этих впадинах и возможный вклад различных механизмов в их образование. Для сравнения рассмотрим сначала данные глубоководного бурения и сейсмического профилирования МОВ-ОГТ по хребту Ломоносова, где континентальная природа коры общепризнана.

\section{ОСАДКОНАКОПЛЕНИЕ И ДВИЖЕНИЯ КОРЫ НА ХРЕБТЕ ЛОМОНОСОВА В КОНЦЕ ПОЗДНЕГО МЕЛА И В КАЙНОЗОЕ}

О процессах в земной коре на большей части площади Амеразийского бассейна можно судить в основном по косвенным данным - сейсмическим, гравиметрическим и геомагнитным. В последние годы со дна моря в нем был поднят большой объем образцов пород [Морозов и др., 2013]. Их происхождение часто подвергается, однако, сомнению в связи с вероятностью ледового разноса. Глубоководное бурение с отбором крупных объемов керна проводилось только вблизи Северного полюса в осевой зоне хребта Ломоносова (рис. 1) [Moran et al., 2006; Backman et al., 2006]. Полученные здесь данные используются как основной репер для интерпретации многочисленных сейсмических исследований, проведенных в западной части Амеразийского бассейна.

На основе результатов бурения по проекту АCEX был составлен сводный разрез, включающий 428 м осадков конца позднего мела и кайнозоя (рис. 2). В самой нижней части разреза были вскрыты прибрежно-морские отложения кампана и, возможно, маастрихта. В дальнейшем, согласно сделанным оценкам [Backman et al., 2006], на интервале времени от 72 до 56 млн. лет назад в районе бурения имел место перерыв, после чего осадконакопление возобновилось в эоцене. В результате эоценовые осадки с размывом залегают на отложениях кампана (или маастрихта), что фиксируется ясно выраженной поверхностью посткампанского несогласия pCU (post-Campanian Unconformity, [Poselov et al., 2014]).

В раннем и в начале среднего эоцена на интервале 56-44 млн. лет назад осадконакопление в рассматриваемой области продолжалось с небольшими перерывами в мелководных условиях (см. рис. 2) [Jakobsson et al., 2008]. В данную эпоху, соответствующую периоду «greenhouse», в Центральной Арктике существовал обширный полуизолированный бассейн, где отлагались отложения с большим количеством органических остатков. В нижней части разреза преобладают морские фации, а в его верхах - пресноводные. В среднем эоцене 44 млн. лет назад произошло осушение этой области, длившееся в течение 26 млн. лет до раннего миоцена. Осадконакопление возобновилось около 18 млн. лет назад в раннем миоцене. С этого момента до настоящего времени здесь в обстановках «icehouse» формировались пелагические осадки, бедные органическим материалом [Backman et al., 2006]. С началом их накопления связано образование несогласия, широко распространенного по всей Центральной Арктике и называемого региональным несогласием RU (Regional unconformity, [Poselov et al., 2014]).

История развития осадконакопления на хребте Ломоносова, кратко изложенная выше, может быть использована в качестве аргументации при определении природы земной коры, залегающей под хребтом и под некоторыми другими глубоководными областями. Океаническая кора образуется в результате спрединга на оси разрастающихся хребтов на глубинах в несколько километров. После этого она испытывает погружение в дрейфующей плите вместе с нижележащей мантией вследствие своего охлаждения. В течение первых 40-50 млн. лет увеличение глубины воды $h_{\text {в }}$ на отодвигающейся плите со временем $t$ достаточно хорошо описывается соотношением [Watts, 2001]

$$
h_{\mathrm{B}}=h_{\mathrm{B}}{ }^{0}+\left(h_{\mathrm{B}}{ }^{1}-h_{\mathrm{B}}{ }^{0}\right)\left(\mathrm{t} / \mathrm{t}_{0}\right)^{1 / 2} \text {, }
$$


где $h_{\mathrm{B}}{ }^{0}$ - глубина воды на оси хребта в начальный момент времени, $h_{\mathrm{B}}{ }^{1}=5000-5500 \mathrm{M}-$ конечная глубина воды в океанических котловинах за пределами хребта, $t_{0}$ - время, в течение которого продолжается образование коры на хребте и ее погружение. Это время соответствует возрасту коры. Для большинства современных океанов оно составляет $t_{0}=$ 80 млн. лет.

Приведенные выше данные глубоководного бурения по проекту АCEX показывают, что с конца кампана до середины раннего миоцена в течение 54 млн. лет земная кора в области хребта Ломоносова располагалась вблизи уровня моря (рис. 3). Океаническая кора могла подстилать эту область в двух случаях. Во-первых, если она образовалась в результате спрединга более, чем за 100 млн. лет до позднего кампана, когда океаническая впадина уже находилась на полностью охладившейся литосферной плите и была заполнена осадками. Как следует из соотношения (2), для компенсации такой океанической впадины глубиной $h_{\mathrm{B}}=5$ км требуется 17 км осадков. В действительности мощность осадков в осевой зоне хребта согласно сейсмическим данным [Jokat, 2005; Poselov et al., 2014] не превышает нескольких километров (рис. 4), и это исключает существование глубоко под осадками, слагающими хребет, древней остывшей океанической коры.

Другая возможность состоит в том, что новообразованная океаническая кора могла бы десятки миллионов лет оставаться вблизи уровня моря, формируясь за счет спрединга в пределах большой вулканической провинции над мощным мантийным плюмом. Высокое гипсометрическое положение поверхности коры поддерживается там сильно разогретым материалом с пониженной плотностью. Такие области характеризуются интенсивным вулканизмом, что в настоящее время наблюдается, например, в Исландии. В меловое время выше уровня моря находилось вулканическое плато Кергелен [Coffin, 1992]. Кора может оставаться в таком положении, пока находится над плюмом, и на ней продолжается вулканизм. После смещения дрейфующей плиты в сторону от плюма вулканическая активность завершается, и начинается охлаждение коры вместе с подстилающей мантией. В результате (см. рис. 3) ситуация развивается примерно по тому же закону, по которому происходит погружение коры, образованной в зоне спрединга (вне пределов больших магматических провинций) - со скоростью, пропорциональной квадратному корню из времени $t$ [Coffin, 1992]. В таком случае с позднего турона до миоцена на хребте Ломоносова проявлялся бы интенсивный вулканизм. Однако никаких проявлений вулканизма на хребте Ломоносова в эту эпоху не наблюдалось. Таким образом, имеющиеся данные показывают, что земная кора на хребте Ломоносова может относиться только к континентальному типу.

Существует и другое свидетельство континентальной природы коры на хребте Ломоносова, которое может быть использовано и по отношению к расположенным восточнее областям Амеразийского бассейна. Это - сближенное положение в разрезе посткампанского (pCU) и регионального (RU) несогласий, отчетливо выраженное на больших площадях. Оба несогласия разделены длительным интервалом времени. Его продолжительность по разным оценкам может составлять от 56 до 26-30 млн. лет, но между ними залегают лишь 200-300 м осадков. Это условно соответствует крайне низкой средней скорости осадконакопления (менее 6,6 мм/тыс. лет), что может быть результатом широкого проявления мелководной конденсации.

Следует отметить, что на рассматриваемом интервале времени движения коры в области глубоководного бурения имели достаточно сложный характер. В конце позднего мела и в палеоцене кора в течение 16 млн. лет находилась выше уровня моря, так что осадконакопления не происходило. Накопление 200 м осадков продолжалось в течение 12 млн. лет в первой половине эоцена (см. рис. 2 и 3). С середины эоцена до бурдигальского века в раннем миоцене осадконакопление прекратилось на 26 млн. лет. Такой неравномерный характер движений также не характерен для коры океанического типа. В 
отсутствие интенсивного вулканизма она может испытывать лишь равномерное погружение.

Сближенное расположение несогласий RU и pCU хорошо прослеживается на сейсмических профилях, проведенных через хребет Ломоносова в различных местах и в разных направлениях [Jokat, 2005; Рекант и др., 2015]. На профиле А7 (рис. 4), проложенном вдоль восточного склона хребта [Poselov et al., 2014], несогласия pCU и RU сливаются в одну линию. Таким образом, можно заключить, что в палеогене в российском секторе Арктики хребет Ломоносова на всем своем протяжении располагался вблизи уровня моря.

\section{КОТЛОВИНА ПОДВОДНИКОВ}

В Российском секторе Амеразийского бассейна наибольшие мощности осадков характерны для котловины Подводников. Эта структура пересечена рядом сейсмических профилей, вскрывающих строение осадочного чехла и поверхности складчатого основания [Weigelt et al., 2014; Рекант и др., 2015; Пискарев и др., 2017 и др.]. Представления о природе консолидированной коры во впадине достаточно противоречивы. Существование океанической коры во впадине предполагается рядом авторов [Lawver et al., 2002; Grantz et al., 2011; Mooney, 2007; Jokat et al., 2013; Dore et. al, 2015; Nikishin et al., 2017]. В работе [Weigelt et al., 2014] показано, что в западную часть котловины проникает континентальная кора восточного склона хребта Ломоносова, испытавшая сильное растяжение и погружение. Предполагается, что в восточной части котловины залегает кора океанического типа. В данной области скорости продольных волн в фундаменте 6.1-6.4 км/с характерны, однако, для гранитного слоя континентальной коры.

На рис. 5 представлен поперечный профиль в субширотном направлении через хребет Ломоносова и котловину Подводников. Из осевой зоны хребта региональное и посткампанское несогласия RU и pCU прослеживаются на восточный склон и далее в котловину Подводников. На большей части профиля интервал глубин между ними составляет 100-200 м, что указывает на крайне низкую среднюю скорость погружения коры. Под рефлектором pCU на фундаменте залегают 3-4 км осадков, что исключает заполнение ими впадины на океанической коре. Над региональным несогласием RU на хребте Ломоносова в котловине расположены толщи осадков мощностью 1.0-1.5 км и 3 км воды. Как следует из соотношения (2), для компенсации впадины с такой глубиной воды, требуется около 7 км осадков. Таким образом, общая мощность осадков, необходимая для заполнения впадин на хребте Ломоносова и в котловине Подводников, составляет 1112 км. При этом основная часть погружения коры произошла уже после длительного периода резкого замедления погружения или даже его прекращения и проявления небольших поднятий. Отложения данного периода сверху и снизу ограничены несогласиями соответственно RU и pCU. При малой мощности этого интервала внедрение крупных масс магматического материала исключается. В таких условиях на охлаждающейся океанической плите погружение не могло практически прекратиться на время около 50 млн. лет и после этого резко ускориться в миоцене. Такое развитие движений могло осуществиться только на коре континентального типа.

На рис. 6 представлен продольный профиль через котловину Подводников. Строение осадочного чехла здесь близко к показанному на поперечном профиле (см. рис. 5). Основное отличие заключается в существовании крупного выступа акустического фундамента в южной части котловины. Как и на поперечном профиле, интервал мощности между несогласиями pCU и RU не превышает нескольких сотен метров, что указывает на крайне низкую среднюю скорость погружения коры. Более того, в южной части профиля брукское несогласие BU залегает лишь на 100-200 м глубже посткампанского несогласия pCU несмотря на то, что по времени они разделены интервалом в 53 млн. лет. Это означает, что данная область в общей сложности более 100 млн. лет находилась вблизи 
уровня моря, что возможно только для коры континентального типа. В акустическом фундаменте здесь наблюдается крупный выступ, с формированием которого мог быть связан подъем рефлектора BU близко к несогласию pCU. Под несогласиями на фундаменте залегают несколько километров осадков, а над региональным несогласием RU в котловине расположены 1.0-1.5 км осадков и 3 км воды. Как и на профиле рис. 5, основная часть погружения коры здесь произошла уже после формирования несогласий pCU и RU, вне зависимости от того, к какому времени они относятся. Таким образом, имеющаяся совокупность сейсмических данных, привязанных к скважинам на оси хребта Ломоносова, однозначно указывает на существование континентальной коры также и под котловиной Подводников.

Следует отметить, что на профилях, показанных на рис. 5 и 6 разломы сосредоточены в основном в нижней части разреза. Так, на поперечном профиле (см. рис. 5) на хребте Ломоносова и в котловине Подводников разломы рассекают фундамент, а также юрское и нижнемеловое несогласия JU и LCU, что в ряде мест сопровождается большими смещениями рефлекторов. В брукском несогласии BU в большинстве мест с разломами связаны уже только небольшие деформации. Рассекая в ряде мест несогласия pCU и RU в котловине Подводников, их существенными смещениями разломы не сопровождаются. Похожая картина наблюдается и на продольном профиле через котловину Подводников (см. рис. 6). Значительные деформации рефлекторов здесь также наблюдаются в нижней части разреза. В региональном и посткампанском несогласиях RU и pCU крупные разломы ограничивают только два горста в северной части профиля, образованные локальными поднятиями фундамента. Таким образом, главные погружения коры, образовавшие с середины раннего миоцена глубоководные впадины, существенным растяжением коры не сопровождались.

\section{КОТЛОВИНА МАКАРОВА}

Этот небольшой бассейн находится на продолжении котловины Подводников, но отличается от нее несколько большими батиметрическими отметками 3800 м [Пискарев и др., 2017; Кашубин и др., 2018]. Ромбовидная в плане форма бассейна часто рассматривается как указание на формирование в нем океанической коры по схеме pullapart [Evangelatos, Mosher, 2016 и др.]. Предполагается также существование в пределах бассейна фрагментов коры континентального типа [Langinen et al., 2009]. Мощность осадков в бассейне достигает 2-4 км, а консолидированная кора утонена здесь до 8-12 км. Это рассматривается как указание на ее океаническую природу [Lebedeva-Ivanova et al., 2011].

Пара сближенных региональных несогласий, очень похожая на рефлекторы pCU и $\mathrm{RU}$, фиксируется и в котловине Макарова (рис. 7). В северной части профиля она, повидимому, протягивается сюда со склона хребта Ломоносова, а на юге - из котловины Подводников. Обе поверхности разделены по глубине интервалом в несколько сотен метров. Близкое строение имеет и верхняя часть осадочного разреза мощностью около 1500 м, расположенная над региональным несогласием RU и сформировавшаяся после быстрого погружения коры в раннем миоцене. Мощность осадков, расположенных на рис. 7 ниже несогласия рCU и предположительно относимых к мелу, в несколько раз меньше мощности осадков, залегающих под этой границей на профилях в котловине Подводников (см.рис. 5 и 6). На верхнем профиле на рис.7 в котловине Подводников выделяется брукское несогласие BU с возрастом 125 млн. лет. В котловину Макарова оно не проникает. Это может быть связано с более продолжительным накоплением отложений в котловине Подводников, начавшимся, вероятно, еще в поздней перми.

Близкое по глубине залегание несогласий RU и pCU наблюдается в котловине Макарова и на субширотном профиле (рис. 8). На основной части площади расстояние между ними по вертикали составляет 200-250 м. Как и на субмеридиональном профиле 
(см. рис. 7), мощность меловых осадков, залегающих ниже посткампанского несогласия, очень невелика. Она увеличивается до 1.5 км лишь в узком троге, расположенном у подножья хребта Ломоносова.

Как показывают приведенные данные, в западной части Амеразийского бассейна повсеместно распространены ярко выраженные отражающие горизонты RU и pCU. Иx формирование разделено большим интервалом времени в 54 млн. лет, но по глубине эти рефлекторы отстоят друг от друга всего лишь на несколько сотен метров. На океанической коре, испытывающей быстрое погружение после спрединга, не могли сформироваться отражающие горизонты, близко расположенные по глубине, но возникшие в разные эпохи, отстоящие друг от друга по времени на 50 млн. лет. Такие рефлекторы могли образоваться только на континентальной коре, длительное время располагавшейся вблизи уровня моря. Это однозначно указывает на то, что котловины Подводников и Макарова, как и хребет Ломоносова, подстилаются корой континентального типа.

В таких условиях возникает вопрос, с чем было связано погружение всех этих структур до глубин 1-4 км. Такое погружение часто связывают с растяжением континентальной коры. Ранее было показано, что данный механизм не мог быть причиной погружения коры до глубин порядка 1 км на оси хребта Ломоносова и до 2.0-2.5 км на его склонах [Artyushkov, Chekhovich, 2019].

\section{ОБСУЖДЕНИЕ РЕЗУЛЬТАТОВ}

Проведенное рассмотрение показывает, что вся западная часть Амеразийского бассейна подстилается корой континентального типа, располагавшейся до середины миоцена вблизи уровня моря. Возникает естественный вопрос, что привело к погружению этой коры до глубин 1-4 км. Большой популярностью пользуется связь вертикальных смещений литосферы с динамической топографией, возникающей на кровле астеносферы под действием интенсивных нисходящих конвективных течений в нижележащей мантии [Flament et al., 2013]. Погружения коры, обусловленные этим механизмом, привели бы к появлению в рассматриваемой области высокоамплитудных отрицательных аномалий силы тяжести в свободном воздухе. В действительности здесь наблюдаются слабые положительные аномалии Фая интенсивностью до нескольких десятков миллигал (рис. 5.2.1 в [Пискарев и др., 2017]). Коллизионные процессы вблизи котловин Макарова и Подводников не проявлялись. Это исключает погружения коры вследствие изгибания литосферы вблизи конвергентных границ между плитами [Watts, 2001].

В таких условиях внимание исследователей обращается к растяжению коры как к возможному механизму ее погружения [Nikishin et al., 2017 и др.]. Первоначально он был предложен для Байкальской впадины [Артемьев, Артюшков, 1968; Artemjev, Artyushkov, 1971]. В различных моделях, сформулированных впоследствии [McKenzie, 1978; Wernicke,1985 и др.], до настоящего времени растяжение используется как главный механизм погружения континентальной коры. В качестве свидетельства растяжения коры обычно рассматриваются сбросы на поверхности кристаллического фундамента [Ziegler, 1983 и др.]. Существование сбросов указывает, однако, лишь на то, что погружение коры сопровождалось ее растяжением. Но это еще не означает, что такое растяжение, было достаточным, чтобы обеспечить наблюдаемое погружение.

Вклад растяжения коры в образование котловин Подводников и Макарова. Анализ сейсмических разрезов через несколько сверхглубоких осадочных бассейнов, показывает, что деформации растяжения в их фундаменте были невелики, и что они могли обеспечить лишь небольшую долю наблюдаемого погружения [Артюшков и др., 2014]. Такая ситуация характерна, в частности, для Северо-Баренцевской, Северо-Чукотской и Прикаспийской впадин. Вклад растяжения коры в общее погружение во впадинах, достигающее 20 км, не превышает нескольких километров. Представляет интерес провести аналогичный анализ по отношению к котловинам Подводников и Макарова. 
На рис. 9 представлен субмеридиональный профиль через южную часть котловины Подводников с интерпретациями авторов из [Nikishin et al., 2017] и [Geologic Structures, 2019]. Длина участка верхнего профиля, на котором проинтерпретированы сбросы в фундаменте, составляет $L=340$ км. Для каждого сброса на рис. 9 нами подсчитано растяжение коры, связанное с его образованием. Суммарное растяжение на всех разрывах для участка профиля, где прослеживается фундамент, составляет $\Delta L=38$ км. Интенсивность растяжения

$$
\Delta=L /(L-\Delta L)=1.13
$$

то есть растяжение на рассматриваемом участке составило $13 \%$.

В условиях изостатического равновесия мощность осадков с плотностью $\rho_{о с}$, накопившихся вследствие растяжения в $\beta$ раз коры с плотностью $\rho_{к}$ и начальной толщиной $h_{\mathrm{K}}^{0}$ (при условии полного заполнения осадками), равна

$$
\left.h_{\mathrm{oc}}=\left[\left(\rho_{\mathrm{M}}-\rho_{\mathrm{K}}\right) / \rho_{\mathrm{M}}-\rho_{\mathrm{oc}}\right)\right] h_{\mathrm{K}}^{0}(1-1 / \beta)
$$

Здесь $\rho_{\mathrm{m}}=3330 \mathrm{\kappa г} / \mathrm{M}^{3}$ - плотность мантии. Полагая $\rho_{\mathrm{K}}=2830 \mathrm{\kappa г} / \mathrm{M}^{3}, \rho_{\text {ос }}=2550 \mathrm{\kappa} / \mathrm{M}^{3}, h_{\mathrm{K}}{ }^{0}=40$ км (начальная мощность континентальной коры) находим:

$$
h_{\mathrm{oc}}=2950 \mathrm{M} .
$$

Данная величина близка к средней мощности осадков на профиле $h_{\text {ос }} \sim 2900$ м. Но они перекрыты еще слоем воды толщиной $h_{\text {в }} \sim 3000$ м. Согласно (2) компенсация такой впадины со средней плотностью 2550 кг/м ${ }^{3}$ потребовала бы накопления еще $6700 \mathrm{м}$ осадков. В результате общая мощность осадочного выполнения впадины достигла бы 9600 м. Современная мощность осадков составляет в ней лишь 30\% от данной величины. Таким образом, растяжение коры на профиле рис. 9А (сверху) могло обеспечить не более одной трети ее наблюдаемого погружения.

В рассмотренном примере мы приняли для расчетов структуру фундамента со сбросами, показанную на рис. 16 в работе [Nikishin et al., 2017], что дает максимальную возможную величину растяжения коры. Указанный рисунок фактически представляет собой модифицированную интерпретацию сейсмического профиля, который показан на рис. 5 и взят из оригинальной публикации [Пискарев и др., 2017], (рис. 5.4.3). Для профиля в оригинальной интерпретации [Geologic Structures, 2019], показанной на рис. 9Б, общее растяжение коры, подсчитанное нами по той же схеме, оказывается еще меньше - 30 км. В этом случае мощность осадков, образовавшихся вследствие растяжения коры, составила бы

$$
h_{\mathrm{oc}}=2260 \mathrm{M} \text {, }
$$

т.е. меньше четверти реального погружения.

В действительности выделение сбросов в фундаменте по сейсмическим данным представляет собой весьма неоднозначную задачу. Сбросы обычно показываются в местах потери непрерывной записи отраженного сигнала. Угол падения сброса, как и величина связанного с ним растяжения коры, остаются при этом неопределенными, часто, как и сам факт существования сброса. В результате структуры, показанные как сбросы с малыми углами падения (low-angle normal faults), могут в действительности оказаться просто пологими склонами фундамента. Так, показанные на рис. 9 сбросы, ограничивающие широкое поднятие фундамента в правой части профиля, имеют углы падения всего лишь 6-7․ В осадочных бассейнах, расположенных на континентах, такие пологие сбросы встречаются очень редко. 
Следует отметить, что в котловине Подводников (см. рис. 5 и 6) разломы сосредоточены в основном в нижней части разреза. Так, на поперечном профиле (см. рис. 5) на хребте Ломоносова и в котловине Подводников разломы рассекают фундамент, а также юрское и нижнемеловое несогласия JU и LCU, что в ряде мест сопровождается большими смещениями рефлекторов вдоль разломов. В брукском несогласии BU в большинстве мест с разломами связаны уже только небольшие деформации. Пересекая в ряде мест несогласия pCU и RU в котловине Подводников, их существенными смещениями разломы не сопровождаются. Похожая картина наблюдается и на продольном профиле через котловину Подводников (см. рис. 6). Значительные деформации рефлекторов здесь также наблюдаются в нижней части разреза. В региональном и посткампанском несогласиях RU и pCU крупные разломы ограничивают только три горста в правой части профиля, образованные локальными поднятиями фундамента. Таким образом, главные погружения коры, образовавшие с середины раннего миоцена глубоководную впадину и сопровождавшиеся накоплением 1000-1500 м осадков, существенным растяжением не сопровождались.

На ряде профилей, проложенных через котловины Подводников и Макарова, деформации фундамента, свидетельствующие о значительном растяжении коры, не выделяются. На рис. 10 представлен профиль МАГЭ протяженностью около 300 км, протягивающийся с Восточно-Сибирского шельфа до южной окраины котловины Подводников [Казанин и др., 2017]. Профиль выполнен с помощью косы длиной 8100 м, что обеспечивает высокую детальность разреза. Фундамент показан на нем желтой линией. В левой (широтно ориентированной) части профиля фундамент разбит системой крупных разломов с его километровыми смещениями. Ряд разломов выделяются и в средней части профиля - в прогибе Вилькицкого и на Демидовской седловине. В то же время на переходе к глубоководной котловине Подводников в фундаменте наблюдается лишь один разлом со смещением не более нескольких сотен метров.

Основные механизмы погружения континентальной коры в котловине Подводников. Анализ сейсмических профилей через котловину Подводников показывает, что растяжение коры могло обеспечить лишь несколько десятков процентов ее наблюдаемого погружения. Более того, основные деформации фундамента и осадочного чехла сосредоточены в нижней части чехла, и в его верхнюю часть они почти не проникают. На посткампанском и региональном несогласиях pCU и RU деформаций растяжения практически не наблюдается. Это означает, что, по крайней мере, в течение последних 60-70 млн. лет значительного растяжения коры в котловине Подводников не происходило. Более того, после сильного растяжения коры ее погружение по мере восстановления температурного равновесия в литосфере продолжается в течение 100 млн. лет [McKenzie, 1978]. За период продолжительностью 50 млн. лет, прошедший между формированием несогласий $\mathrm{PCU}$ и RU, погружение коры в котловине Подводников составило 200 м, что составляет лишь два процента от общей мощности осадков, необходимой для полной компенсации впадины ( 10 км). Отсюда следует, что, если в ней и происходило значительное растяжение континентальной коры, то оно закончилось задолго до конца кампана, и к этому времени сформированная растяжением впадина уже была в основном компенсирована осадками.

Основной вклад в образование котловины Подводников внесло погружение в начале миоцена, быстро сформировавшее впадину, заполненную примерно тремя километрами воды. Для компенсации такой впадины потребовалось бы около 7 км осадков, что в несколько раз больше мощности осадков, накопившихся до этого на большей части площади котловины Подводников. Это погружение существенным растяжением уже не сопровождалось. В раннем миоцене вблизи границ котловины не происходило также субдукции в мантию океанической литосферы или надвигания на кору крупных тектонических покровов. Аномалии силы тяжести в свободном воздухе над котловиной очень невелики. На большей части площади они находятся на уровне \pm 10 мГал [Пискарев 
и др., 2017]. Это исключает значительные вертикальные смещения коры под влиянием мантийных течений. В таких условиях в отсутствие заметного растяжения коры для объяснения ее крупного погружения единственной возможностью остается значительное уплотнение пород в литосферном слое. Ранее этот механизм использовался по отношению к образовавшимся без значительного растяжения коры Прикаспийской, ЮжноКаспийской, Северо-Баренцевской и Северо-Чукотской впадинам, а также глубоководной впадины Мексиканского залива [Артюшков и др., 2014]. Погружение коры объяснялось переходом габбро в более плотные гранатовые гранулиты и эклогиты. Такое объяснение для образования впадин в Баренцевом море предлагалось и другими исследователями [Semprich et al., 2010; Gac et al., 2012; Artemieva, Thybo, 2013]. Существование в литосфере крупных масс тяжелого эклогита допускалось также для глубоководной впадины Мексиканского залива [Mooney, Kaban, 2010].

В условиях изостатического равновесия для образования бассейна глубиной $h_{\text {ос, }}$ заполненного осадками с плотностью рос, требуется переход в эклогиты с плотностью $\rho_{э}$ расположенного в нижней части коры слоя габбро с плотностью $\rho_{г б}$ и мощностью

$$
h_{г б}=\left(\rho_{э} / \rho_{м}\right)\left[\left(\rho_{м}-\rho_{о с}\right) /\left(\rho_{\ni}-\rho_{г} \sigma\right)\right] h_{o c} .
$$

В восточной части котловины Подводников мощность осадков, накопившихся с начала миоцена, составляет 2300 м. Осадки перекрыты слоем воды толщиной 2700 м. При

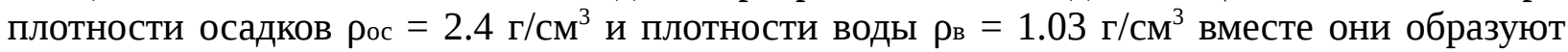

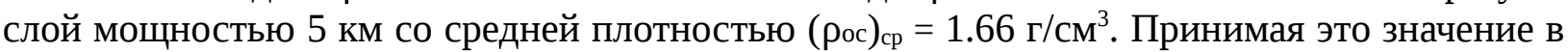

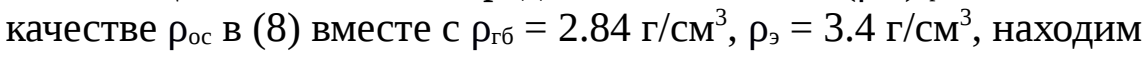

$$
h_{\mathrm{r} \sigma}=8.5 \mathrm{KM} .
$$

Скорости продольных волн в эклогитах примерно такие же, как в мантийных перидотитах [Соболев, Бабейко, 1994; Sobolev, Babeiko, 1994; Christensen N. Mooney, 1995]. В результате слой эклогитов, образовавшихся из габбро и относящийся по своему исходному составу к земной коре, по формальным признакам (сейсмическим характеристикам) должен рассматриваться как часть мантии. Поэтому можно предположить, что под разделом Мохо в котловине Подводников залегает слой эклогитов, который и удерживает кору котловины в глубоко погруженном состоянии. На глубинных профилях МОВ-ОГТ 2014 (01-06) [Пискарев и др., 2017, с.175-176], раздел Мохо расположен на глубинах 19-22 км. С учетом оценки (9) до начала погружения в начале миоцена он мог располагаться на глубинах 28-30 км. В современную эпоху этот раздел располагается на таких глубинах под некоторыми континентальными областями [Chulick, Mooney, 2002; Artemieva, Thybo, 2013].

\section{ЗАКЛЮЧЕНИЕ}

Глубоководные котловины Подводников и Макарова образовались в результате погружения коры, поверхность которой первоначально располагалась вблизи уровня моря. История развития погружения в котловинах резко отлична от типичного развития погружения во времени, характерного для океанической коры, образовавшейся на оси спрединга. Это указывает на континентальную природу коры, залегающей под котловинами. Отсутствие больших деформаций в их фундаменте и в осадочном чехле свидетельствует о том, что вклад растяжения в погружение коры с образованием глубоководных впадин был невелик. В отсутствие значительных аномалий силы тяжести над впадинами их формирование можно связать с уплотнением пород в литосферном слое. Наиболее вероятно, что это уплотнение произошло в нижней коре в результате перехода габброидов в эклогиты, более плотные, чем мантийные перидотиты. Быстрое погружение 
в миоцене было, по-видимому, обусловлено резким ускорением метаморфизма при инфильтрации в кору мантийных флюидов. По своему составу эклогиты относятся к земной коре, но поскольку скорости продольных волн в них близки к скоростям в перидотитах, то расположенный под разделом Мохо слой эклогитов на основании сейсмических данных включают в состав мантии. В результате вышележащая часть коры, расположенная над разделом Мохо, интерпретируется как сильно утоненная континентальная кора в котловине Подводников, или как кора океанического типа в котловине Макарова.

\section{ИСТОЧНИКИ ФИНАНСИРОВАНИЯ}

Представленные в этой статье результаты являются составной частью инициативного научного проекта, поддержанного грантом Российского фонда фундаментальных исследований (РФФИ) № 18-05-00424 А.

\section{ЛИТЕРАТУРА}

Артемьев М.Е., Артюшков Е.В. О происхождении рифтовых впадин // Изв. АН СССР, Сер. Геол., 1968, № 4, с. 58-73.

Артюшков Е.В., Егоркин А.В. Механизм образования Прикаспийской впадины // Доклады Академии наук, 2005, т. 400, № 4, с. 494-499.

Артюшков Е.В., Беляев И.В., Казанин Г.С., Павлов С.П., Чехович П.А., Шкарубо С.И. Механизмы образования сверхглубоких прогибов: Северо-Баренцевская впадина. Перспективы нефтегазоносности. // Геология и геофизика. 2014, т. 55, (5-6), с. 821-846.

Дараган-Сущова Л.А., Петров О.В., Соболев В.В., Дараган-Сущов Н.И., Попова И.В. Геология и история формирования котловины Подводников Северного Ледовитого океана по сейсмическим данным // Региональная геология и металлогения, 2017, (71), с. 5-18.

Казанин Г.С., Барабанова Ю.Б., Кириллова-Покровская Т.А., Черников С.Ф., Павлов С.П., Иванов Г.И. Континентальная окраина Восточно-Сибирского моря: геологическое строение и перспективы нефтегазоносности // Разведка и охрана недр, 2017, (10), с. 51-55.

Кашубин С.Н., Петров О.В., Мильштейн Е.Д., Винокуров И.Ю., Андросов Е.А., Голышева Ю.С., Ефимова Н.Н., Яварова Т.М., Морозов А.Ф. Структура земной коры зоны сочленения поднятия Менделеева с Евразийским континентом (по геофизическим данным) // Региональная геология и металлогения, 2018, (74), с. 5-18.47.

Морозов А.Ф., Петров О.В., Шокальский С.П., Кашубин С.Н., Кременецкий А.А., Шкатов М.Ю., Каминский В.Д., Гусев Е.А., Грикуров Г.Э., Рекант П.В., Шевченко С.С., Сергеев С.А., Шатов В.В. Новые геологические данные, обосновывающие континентальную природу области Центрально-Арктических поднятий // Региональная геология и металлогения, 2013, (53), с. 34-55.

Пискарев А.Л., Поселов В.А., Аветисов Г.П., Буценко В.В., Глебовский В.Ю., Гусев Е.А., Жолондз С.М., Каминский В.Д., Киреев А.А., Смирнов О.Е., Фирсов Ю.Г., Зинченко А.Г., Павленкин А.Д., Поселова Л.Г., Савин В.А., Черных А.А., Элькина Д.В. Арктический бассейн (геология и морфология). Гл. ред. В.Д. Каминский. СПб.: ВНИИОкеангеология, 2017. 291 с.

Поселов В.А., Буценко В.В., Жолондз С.М., Киреев А.А. Структуры растяжения в комплексе Центрально-Арктических подводных поднятий // Геология и геофизика, 2019, т. 60, (1), с. 3-17.

Рекант П. В., Петров О. В., Кашубин С. Н. и др. История формирования осадочного чехла глубоководной части Арктического бассейна по данным сейсмических исследований МОВ ОГТ // Региональная геология и металлогения, 2015, (64), с. 11—27.

Соболев С.В., Бабейко А.Ю. Расчет фазовых равновесий и упругих свойств магматических горных пород // Физика Земли, 1994, (11), с. 3-19 
Artemjev M.E., Artyushkov E.V. Structure and isostasy of the Baikal rift and the mechanism of rifting // J. Geophys. Res. 1971, 76 (5), p. 1197-1211.

Artemieva I.M., Thybo H. Moho depth and crustal structure in Europe, Greenland, and the North Atlantic region // Geophysical Research Abstracts, 2013, v. 15, EGU2013-1791, http://meetingorganizer.copernicus.org/EGU2013/ EGU2013-1791.pdf.

Artyushkov E. V., Chekhovich P. A. Geodynamics of the Lomonosov Ridge in the Central Arctic // Russ. J. Earth. Sci., 2019, № 19, ES1004, doi:10.2205/2018ES000652.

Backman, J., Moran K., McInroy D.B. et al. Sites V0001-M0004 // Proceedings of the Integrated Ocean Drilling Program, 2006, 302, 169 p.

Christensen N. Mooney W. Seismic velocity structure and composition of the continental crust: A global view // J. Geophys. Res., 1995, v. 100, p. 9761-9788.

Chulick G., Mooney W.D. Seismic Structure of the Crust and Uppermost Mantle of North America and Adjacent Oceanic Basins: A Synthesis // Bulletin of the Seismological Society of America, 2002, 92(6), p. 2478-2492.

Coffin M.F. Emplacement and subsidence of Indian Ocean plateaus and submarine ridges. In, Duncan R.A., Rea D.K., Kidd R.B., von Rad U. and Weissel J.K. (eds.) Synthesis of results from Scientific Drilling in the Indian Ocean. 1992. Washington DC, USA. American Geophysical Union, p. 115-125. (AGU Geophysical Monograph, 70).

Doré A. G., Lundin E. R., Gibbons A., Sømme T. O., Tørudbakken B. O. Transform margins of the Arctic: a synthesis and re-evaluation // Geological Society, London, Special Publications, 2015, (431), p. 63-94.

Evangelatos J., Mosher D.C. Seismic stratigraphy, structure and morphology of the Makarov Basin: tectonic implications // Mar. Geol., 2016, (374), p. 1-13.

Evangelatos J., Funk T., Mosher D.C. The sedimentary and crustal structure of the Makarov Basin and adjacent Alpha Ridge // Tectonophysics, 2017, (696-697), p. 99-114.

Flament N., Gurnis M., Müller R.D. A review of observations and models of dynamic topography // Lithosphere, 2013, 5, (2). p. 189-210. doi: 10.1130/L245.

Gac, S., Huismans, R.S., Podladchikov, Yu.Yu., Faleide, J.Y. On the origin of the ultradeep East Barents Sea basin // J. Geophys. Res., 2012. (117), B04401. doi: 101029/2011JB008533.

Geologic Structures of the Arctic Basin / Eds. Alexey Piskarev, Victor Poselov, Valery Kaminsky, Springer International Publishing, 2019. 375 p. doi: 10.1007/978-3-319-77742-9.

Goldner A, Herold N, Huber M. Antarctic glaciation caused ocean circulation changes at the Eocene-Oligocene transition // Nature, 2014, 511(7511), p. 574-7. doi: 10.1038/nature13597.

Grantz A., Hart P., Childers V. Geology and tectonic development of the Amerasia and Canada Basins, Arctic Ocean. In: Spencer A.M., Embry A.F., Gautier D.L., Stoupakova A.V., Sørensen K. (Eds.). Arctic Petroleum Geology. Geological Society (London) Memoirs, 2011, (35), p. 771-799.

Jakobsson M., Macnab R., Mayer L., Anderson R., Edwards M., Hatzky J., Schenke W., Johnson P. An improved bathymetric portrayal of the Arctic Ocean: Implications for ocean modeling and geological, geophysical and oceanographic analyses // Geophysical Research Letters. 2008, (35), L07602, doi:10.1029/2008GL033520

Jakobsson M., L. A. Mayer, B. Coakley, J. A. Dowdeswell, S. Forbes, B. Fridman, H. Hodnesdal, R. Noormets, R. Pedersen, M. Rebesco, H.-W. Schenke, Y. Zarayskaya A, D. Accettella, A. Armstrong, R. M. Anderson, P. Bienhoff, A. Camerlenghi, I. Church, M. Edwards, J. V. Gardner, J. K. Hall, B. Hell, O. B. Hestvik, Y. Kristoffersen, C. Marcussen, R. Mohammad, D. Mosher, S. V. Nghiem, M. T. Pedrosa, P. G. Travaglini, and P. Weatherall, The International Bathymetric Chart of the Arctic Ocean (IBCAO) Version 3.0, Geophysical Research Letters. 2012, (39), L12609, doi:10.1029/2012GL052219.

Jokat W. The sedimentary structure of the Lomonosov Ridge between $88^{\circ} \mathrm{N}$ and $80^{\circ} \mathrm{N} / /$ Geophysical Journal International, 2005, (163), p. 698-726, doi: 10.1111/J.1365246X.2005.02786.x. 
Jokat W., Ickrath M., O’Connor J. Seismic transect across the Lomonosov and Mendeleev Ridges: Constraints on the geological evolution of the Amerasia Basin, Arctic Ocean // Geophysical Research Letters, 2013, (40), p. 5047-5051. doi:10.1002/grl.50975.

Langinen A., Lebedeva-Ivanova N., Gee D., Zamansky Yu. Correlation between the Lomonosov Ridge, Marvin Spur and adjacent basins of the Arctic basin based on seismic data Tectonophysics, 2009, (472), p. 309-322.

Lawver L.A., Grantz A. and Gahagan L.M. Plate kinematic evolution of the present Arctic region since the Ordovician // Spec. Pap. Geol. Soc. Am., 2002, (360), p .333-358. DOI: 10.1130/0-8137-2360-4.333

Lebedeva-Ivanova N.N., Gee D.C., Sergeev M.B. Crustal structure of the East Siberian continental margin, Podvodnikov and Makarov basins, based on refraction seismic data (TransArctic 1989-1991) // Geol Soc. Lond. Mem., 2011, (35), p. 395-411.

McKenzie D. Some remarks on the development of sedimentary basins // Earth and Planet. Sci. Lett. 1978, (40), p. 25-32.

Mooney W.D. Crust and Lithospheric Structure - Global Crustal Structure. Treatise on Geophysics, vol. 1: Seismology and Structure of the Earth. (Eds. B. Romanowicz \& A. Dziewonski). Elsevier, 2007, p. 361-417.

Mooney W.D., Kaban M.K. The North American upper mantle: Density, composition, and evolution // J. Geophys. Res. Solid Earth, 2010, 115 (B12), doi: 10.1029/2010JB000866.

Moran K., Backman J., Brinkhuis Y. et al. The Cenozoic paleoenvironment of the Arctic Ocean. // Nature, 2006, 444, p. 601-606.

Nikishin A.M., Petrov E.I., Malyshev N.A., Ershova V.P. Rift systems of the Russian Eastern Arctic shelf and Arctic deep-water basins: link between geological history and geodynamics // Geodynamics \& Tectonophysics, 2017, 8 (1), p. 11-43. doi:10.5800/GT-2017-8-1-0231.

Oakey G.N., Saltus R.W. Geophysical analysis of the Alpha-Mendeleev ridge complex: Characterization of the High Arctic Large Igneous Province // Tectonophysics, 2016, (691), Part A, p. 65-84. doi:10.1016/j.tecto.2016.08.005.

Olson P., Amit H. Mantle superplumes induce geomagnetic superchrons // Front. Earth Sci. 2015. 3 (38). doi: 10.3389/feart.2015.00038.

Petrov O., Morozov A., Shokalsky S., Kashubin S., Artemeva I.M., Sobolev N., Petrov E., Ernst R.E., Sergeev S., Smelror M. Crustal structure and tectonic model of the Arctic region // Earth-Science Reviews, 2016, (154), p. 29-71.

Poselov V., Butsenko V., Chernykh A., Glebovsky V., Jackson H., Potter D., Oakey G., Shimeld J., Marcussen C. The structural integrity of the Lomonosov Ridge with the North American and Siberian continental margins. SPb.: VSEGEI, 2014, p. 233- 258.

Semprich J., Simon N.S.C., Podladchikov Yu. Density variations in the thickened crust as a function of pressure, temperature, and composition // Int. J. Earth Sci., 2010, 99, № 7, p. 14871510, doi: 10.1007/s00531-010-0557-7.

Sobolev S.V., Babeyko A.Y. What drives orogeny in the Andes // Geology, 2005, (33), № 8, p. $617-620$.

Watts A.B. Isostasy and Flexure of the Lithosphere. Cambridge University Press. 2001. 458 pp.

Weigelt E., Jokat W., Franke D. Seismostratigraphy of the Siberian Sector of the Arctic Ocean and adjacent Laptev Sea Shelf // Journal of Geophysical Research, 2014, (119), № 7, p. $5275-5289$.

Wernicke B. Uniform-sense normal simple shear of the continental lithosphere // Canadian Journal of Earth Sciences, 1985, (22), № (1), p. 108-125, https://doi.org/10.1139/e85-009.

Ziegler P.A. Crustal thinning and subsidence in the North Sea // Nature, 1983, (304), № 5926, p. 561. 


\section{Подписи к рисункам в статье Артюшкова и др.}

Рис. 1. Глубоководные прогибы Центральной Арктики - по IBCAO (ver. 3) [Jakobsson et al., 2012]. Профили, представленные на рис. 5 - 10, показаны красными жирными линиями и стрелками.

Рис. 2. Характер осадконакопления по данным бурения скважин по проекту ACEX на хребте Ломоносова [Backman et al., 2006].

Рис. 3. Погружение коры различного типа во времени

Рис. 4. Фрагмент профиля А7 на хребте Ломоносова [Poselov et al., 2014; с изменениями]. Здесь и далее на рис. 5-8 местоположение разреза отмечено жирным отрезком на врезке.

Рис.5. Глубинный сейсмический разрез через хребет Ломоносова и котловину Подводников вдоль профилей 53 и 65 экспедиции Арктика-2011 (из [Geologic Structures, 2019], модифицированный).

Рис. 6. Глубинный сейсмический разрез через котловину Подводников вдоль профилей 58 и 66 экспедиции Арктика-2011 (из [Geologic Structures, 2019], модифицированный).

Рис. 7. Глубинный сейсмический разрез через котловины Подводников и Макарова вдоль профиля 1406 экспедиции Арктика-2014 (из [Geologic Structures, 2019; с изменениями], модифицированный).

Рис. 8. Глубинный сейсмический разрез через котловину Макарова вдоль фрагмента профиля 1407 экспедиции Арктика-2014 (из [Geologic Structures, 2019], модифицированный).

Рис. 9. Оценка суммарного растяжения при формировании котловины Подводников на основе анализа различных вариантов интерпретации сводного сейсмического разреза вдоль профилей 58-66 экспедиции Арктика2011. 
A - в интерпретации [Nikishin et al., 2017]; черной линией показан фундамент, красными линиями - сбросы, выделенные по сейсмическим данным, цифрами - величина растяжения х (км) на индивидуальных сбросах; Б - в интерпретации [Geologic Structures, 2019]. Цифрами (1-21) отмечены индивидуальные сбросы и растяжение на каждом из них (х1 - х21, км). SSB подошва стратифицированного осадочного чехла, JU - юрское несогласие; LCU - нижнемеловое несогласие; BU - брукское несогласие; pCU посткампанское несогласие; RU - региональное (предмиоценовое) несогласие.

Рис. 10. Сводный разрез вдоль композитного профиля ESS1611-ESS1601 (интерпретация ОАО «МАГЭ») [Казанин и др., 2017, с изменениями]. Главные отражающие горизонты (несогласия) в осадочном чехле: А подошва чехла, PU - пермское, JU - юрское, LCU - нижнемеловое, ESS1 $1_{1}$ предверхнемеловое (брукское), ESS1 - посткампанское, ESS2 позднеэоценовое, ESS3 - нижнемиоценовое, ESS5 - нижнеплиоценовое. 


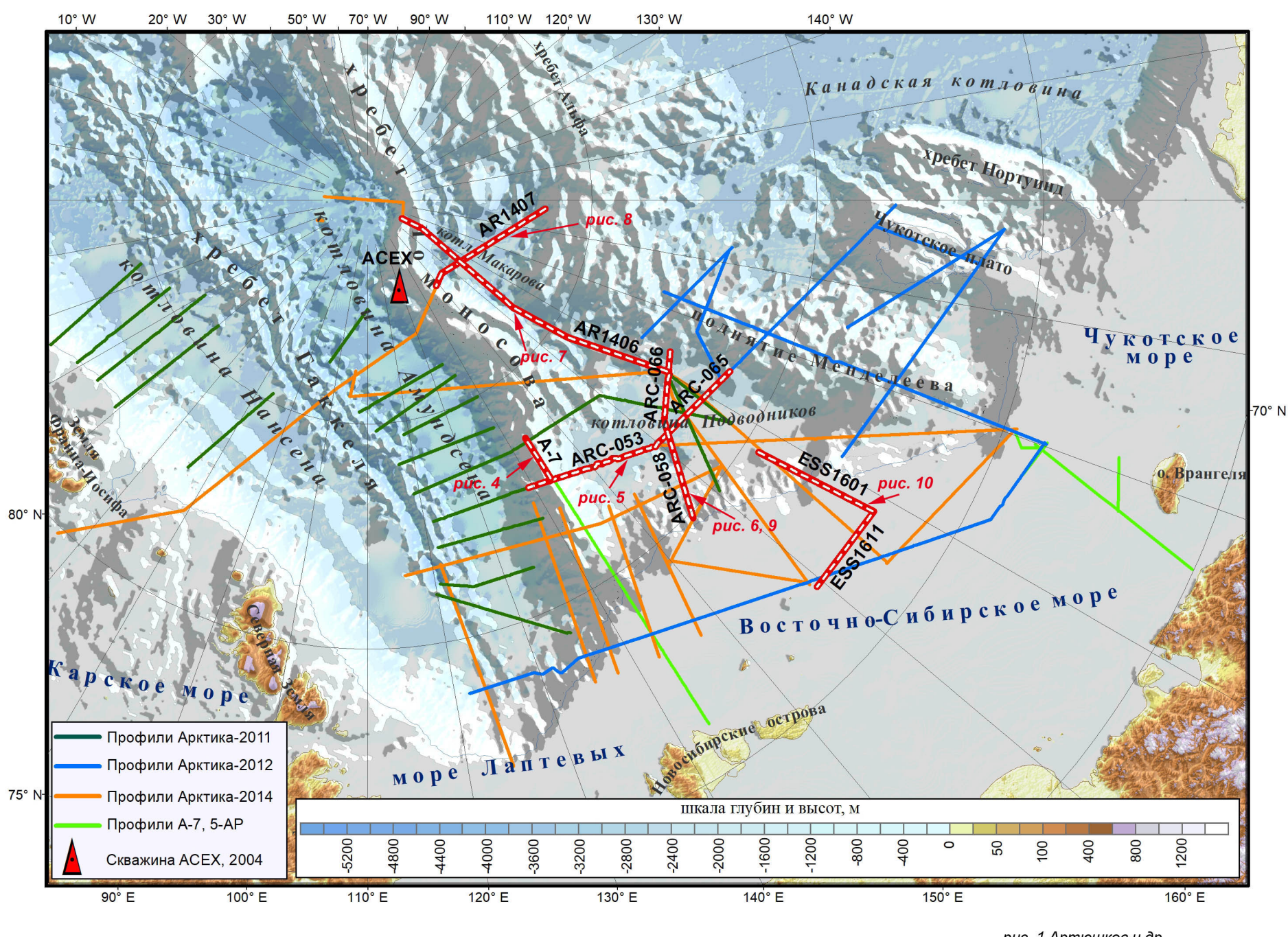

рис. 1 Артюшков и др. 


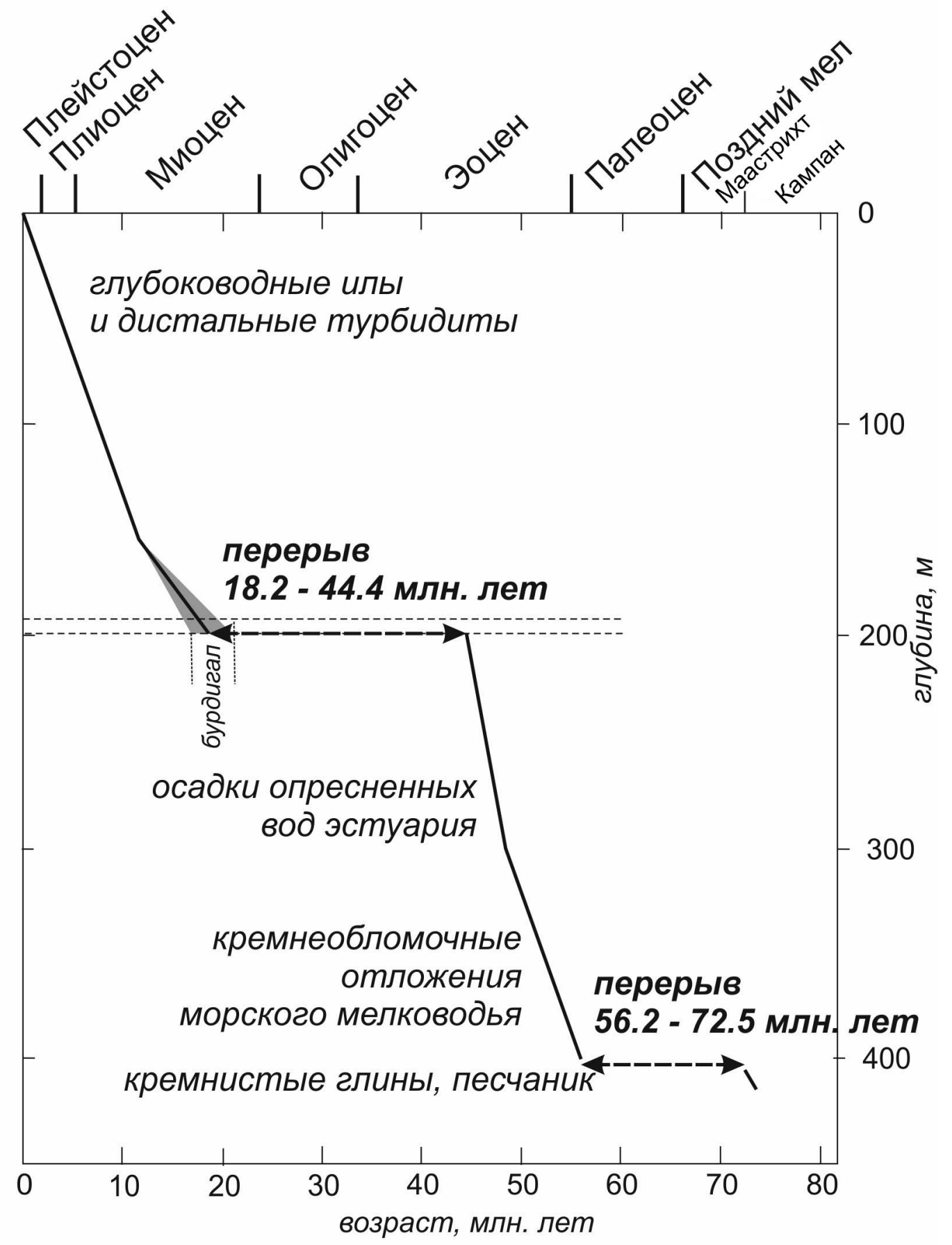

рис. 2 Артюшков и др. 


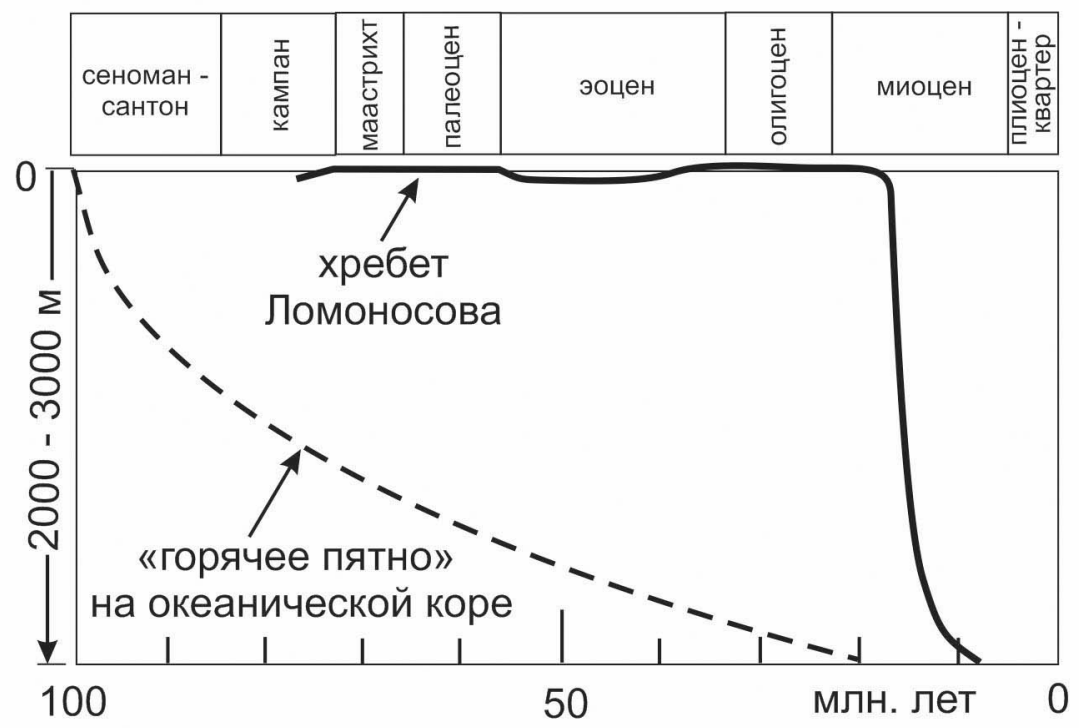

рис. 3 Артюшков и др. 


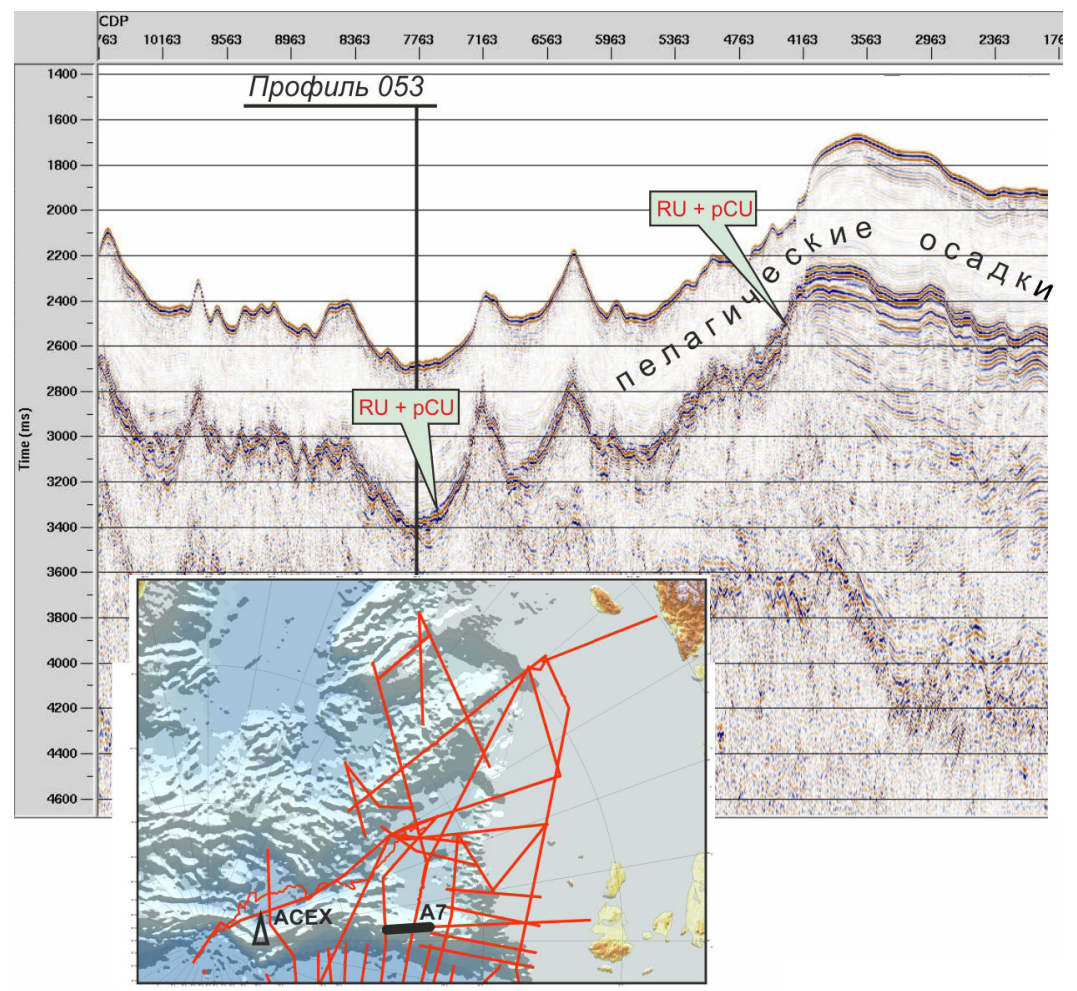

рис. 4 Артюшков и др. 


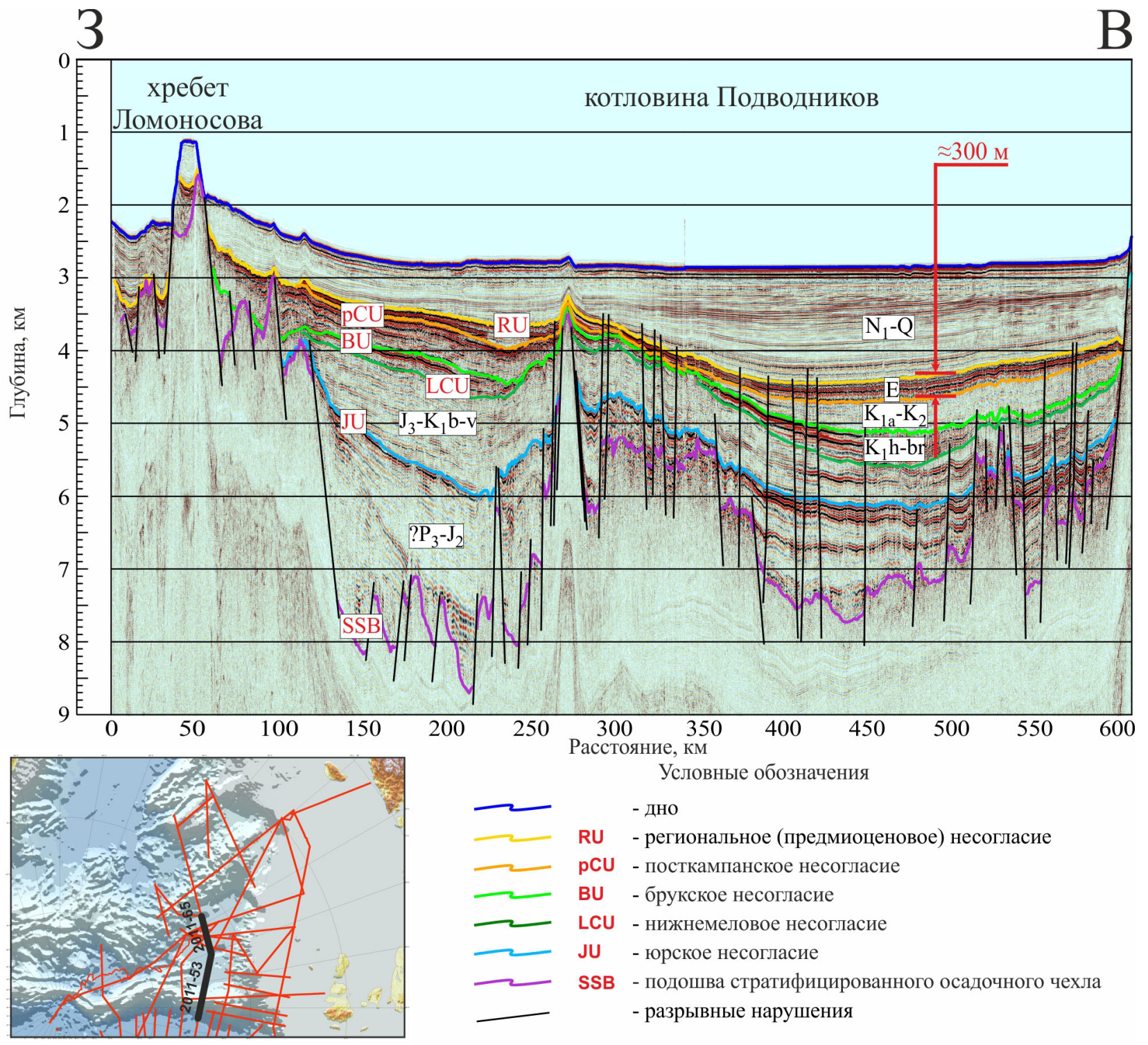

рис. 5 Артюшков и др. 


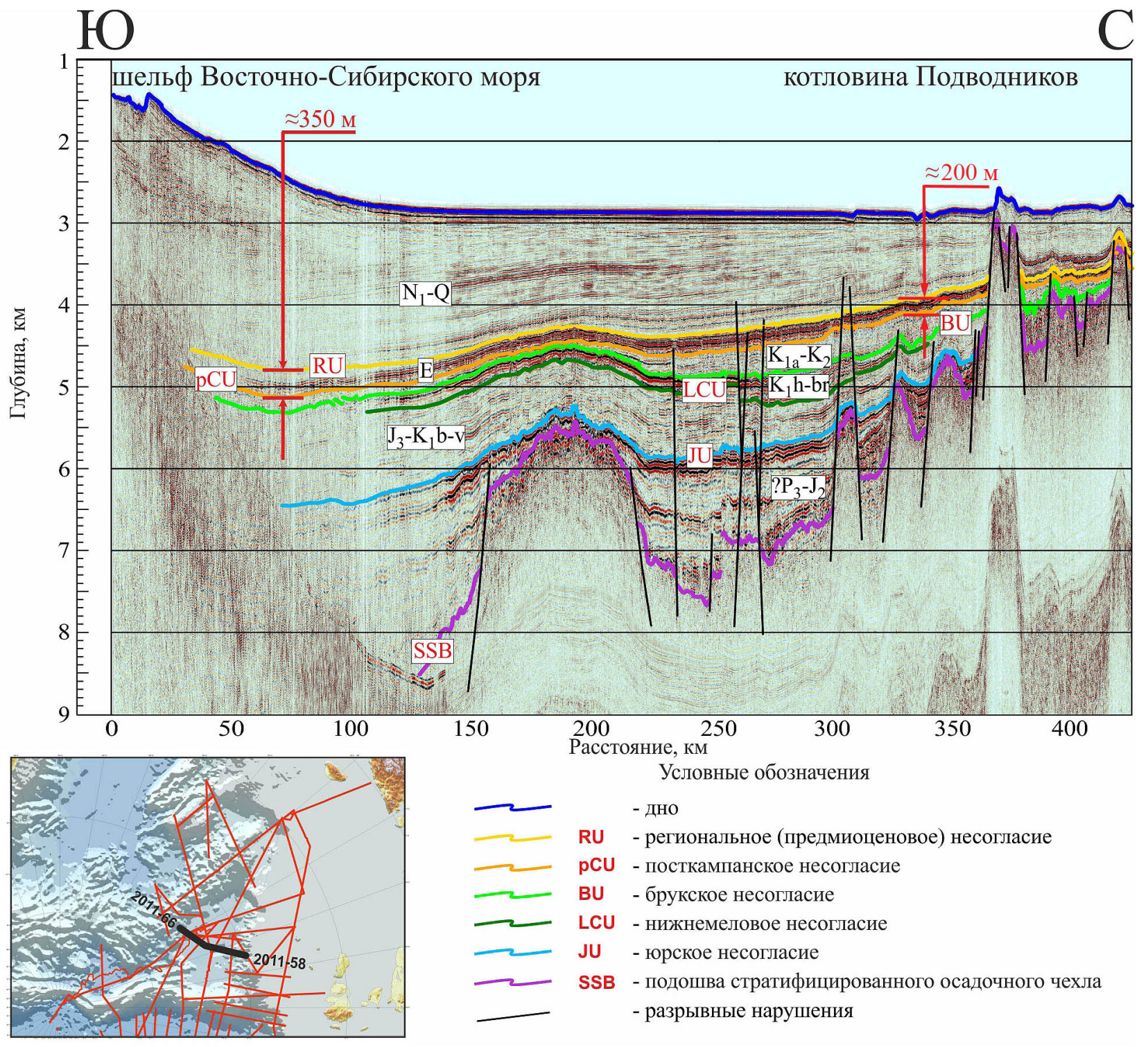

pис. 6 к статье Артюшкова и дp. 


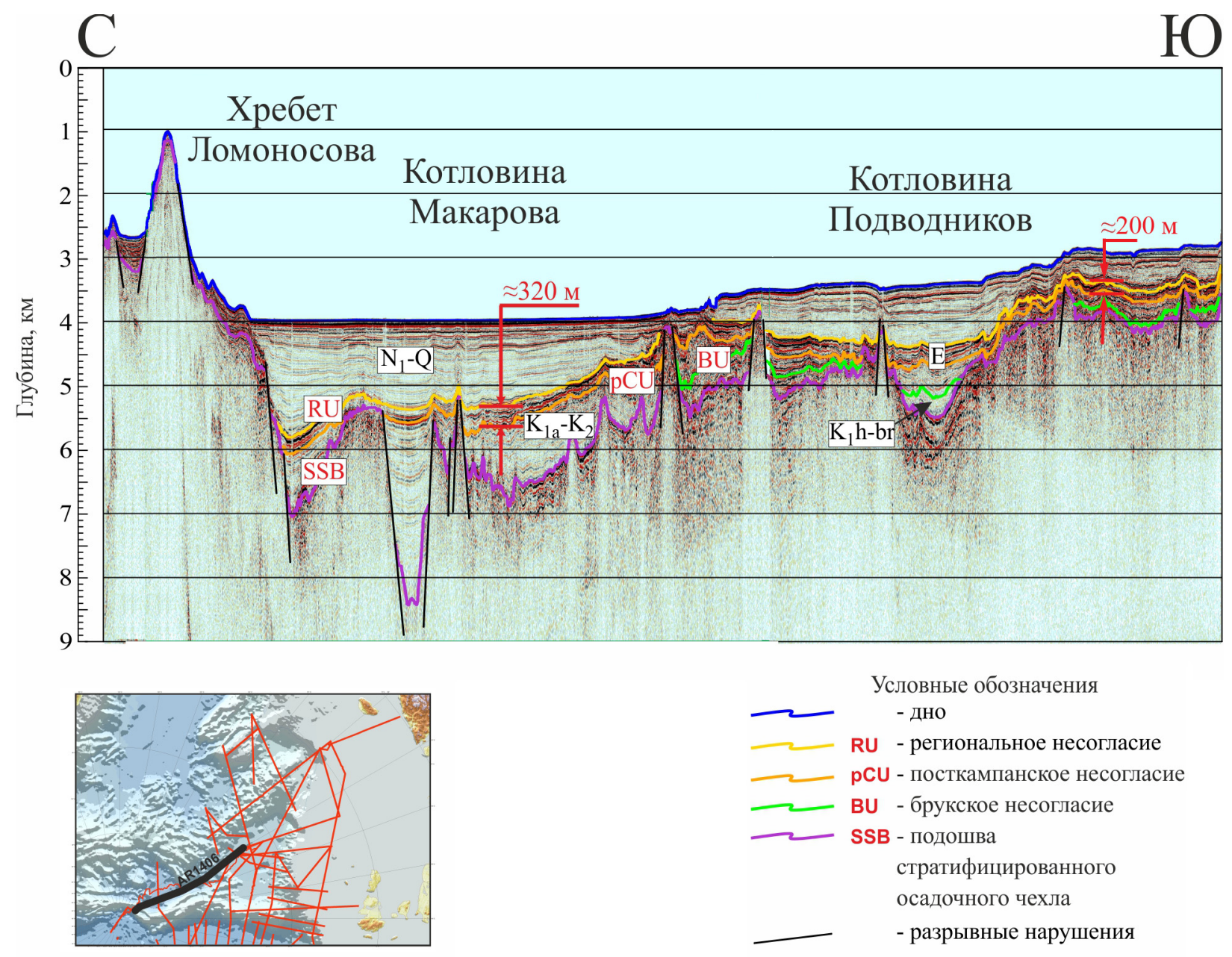

рис. 7 к статье Артюшкова и др. 


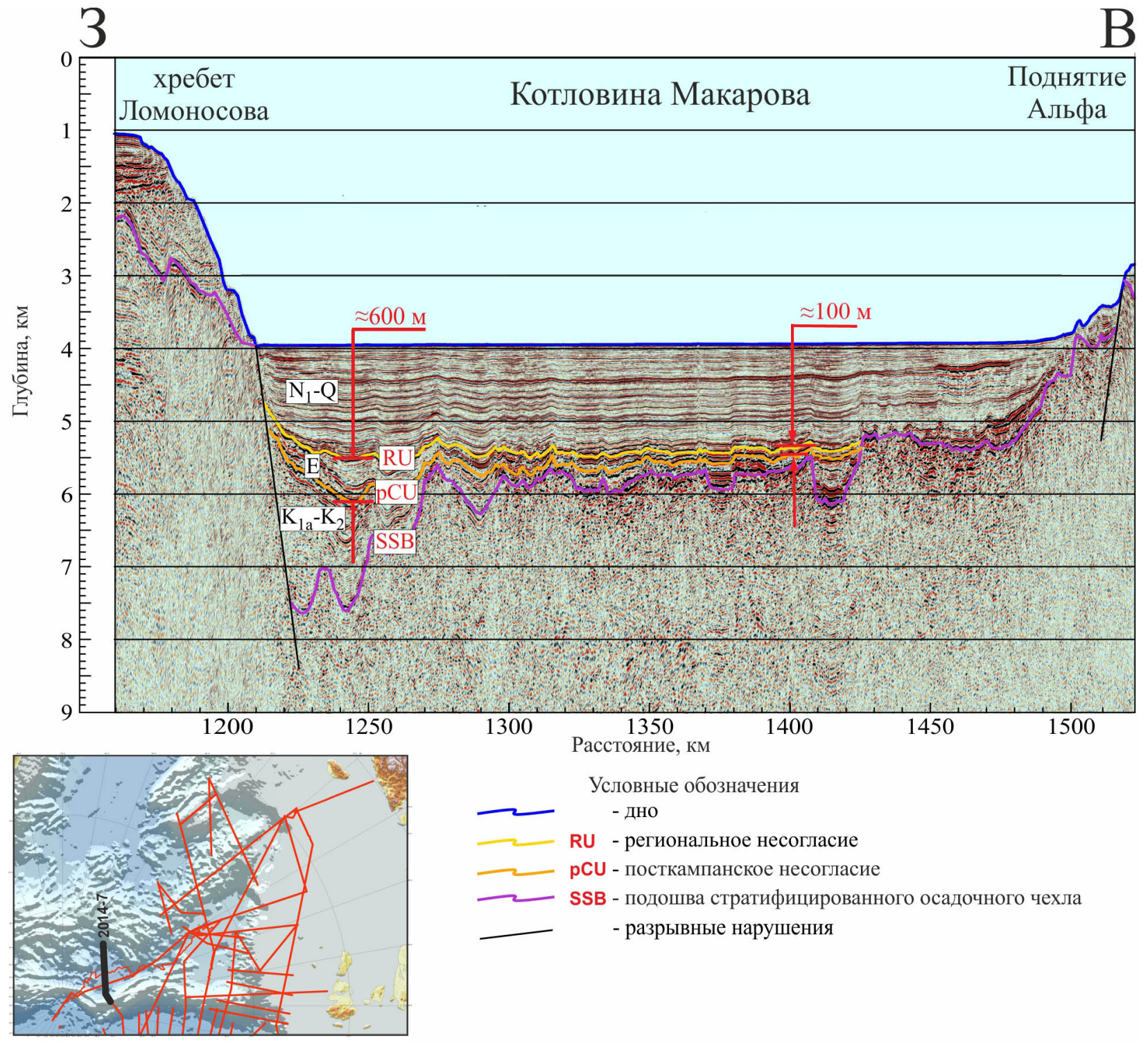

рис. 8 Артюшков и др. 
A

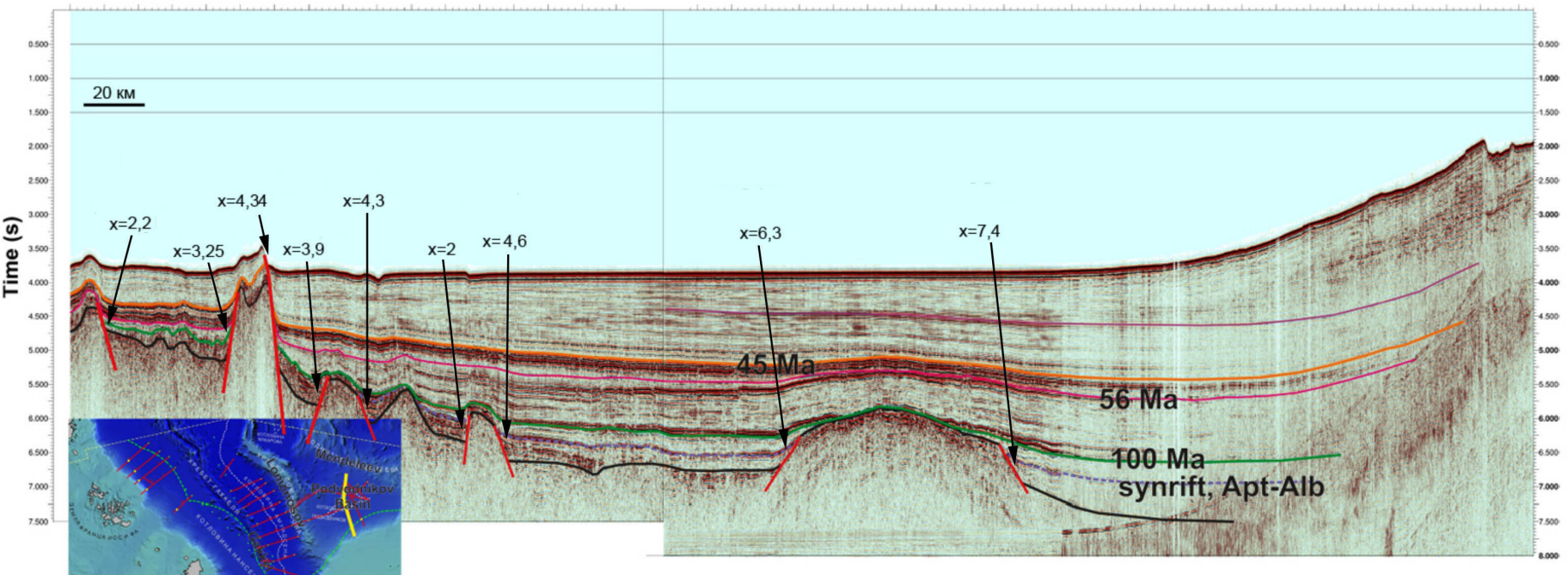

Суммарное растяжение - 38,3 км

Б

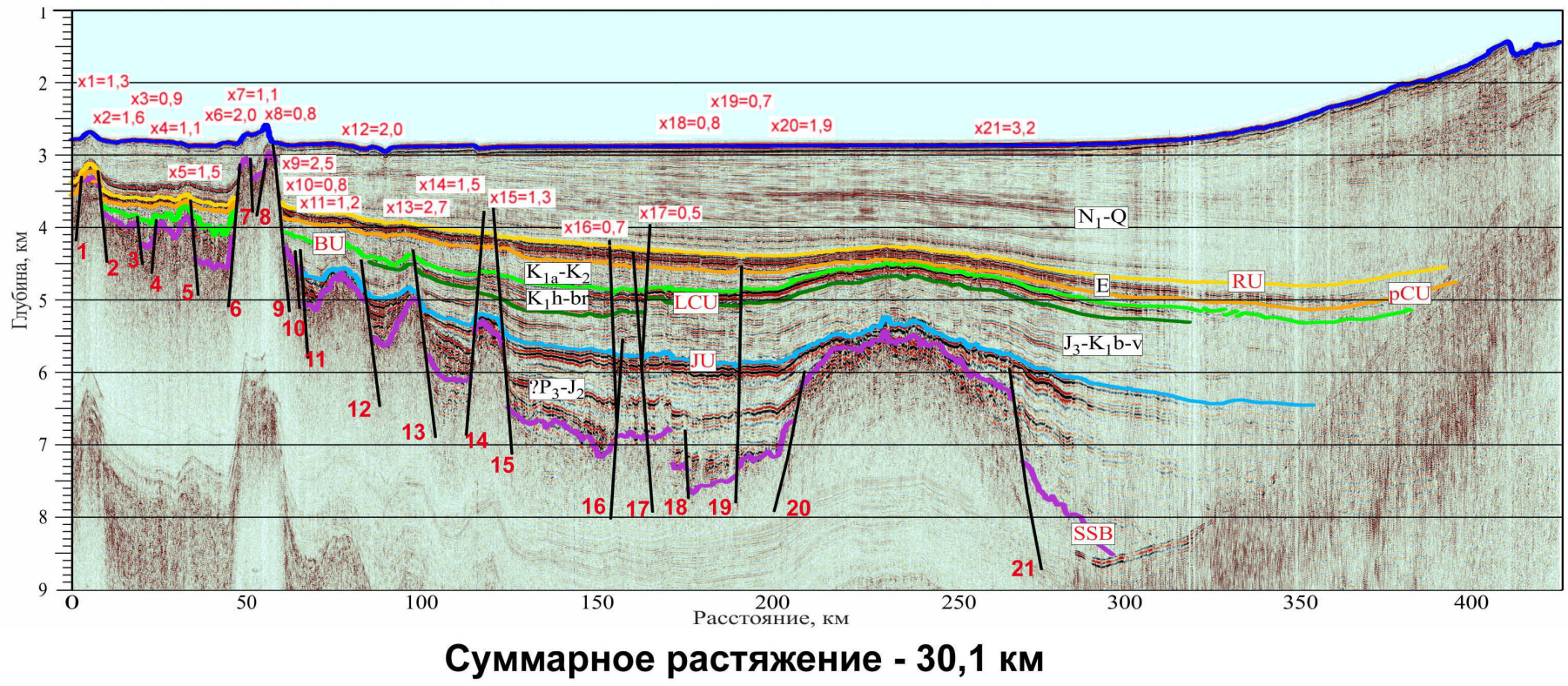

рис. 9 Артюшков и др. 


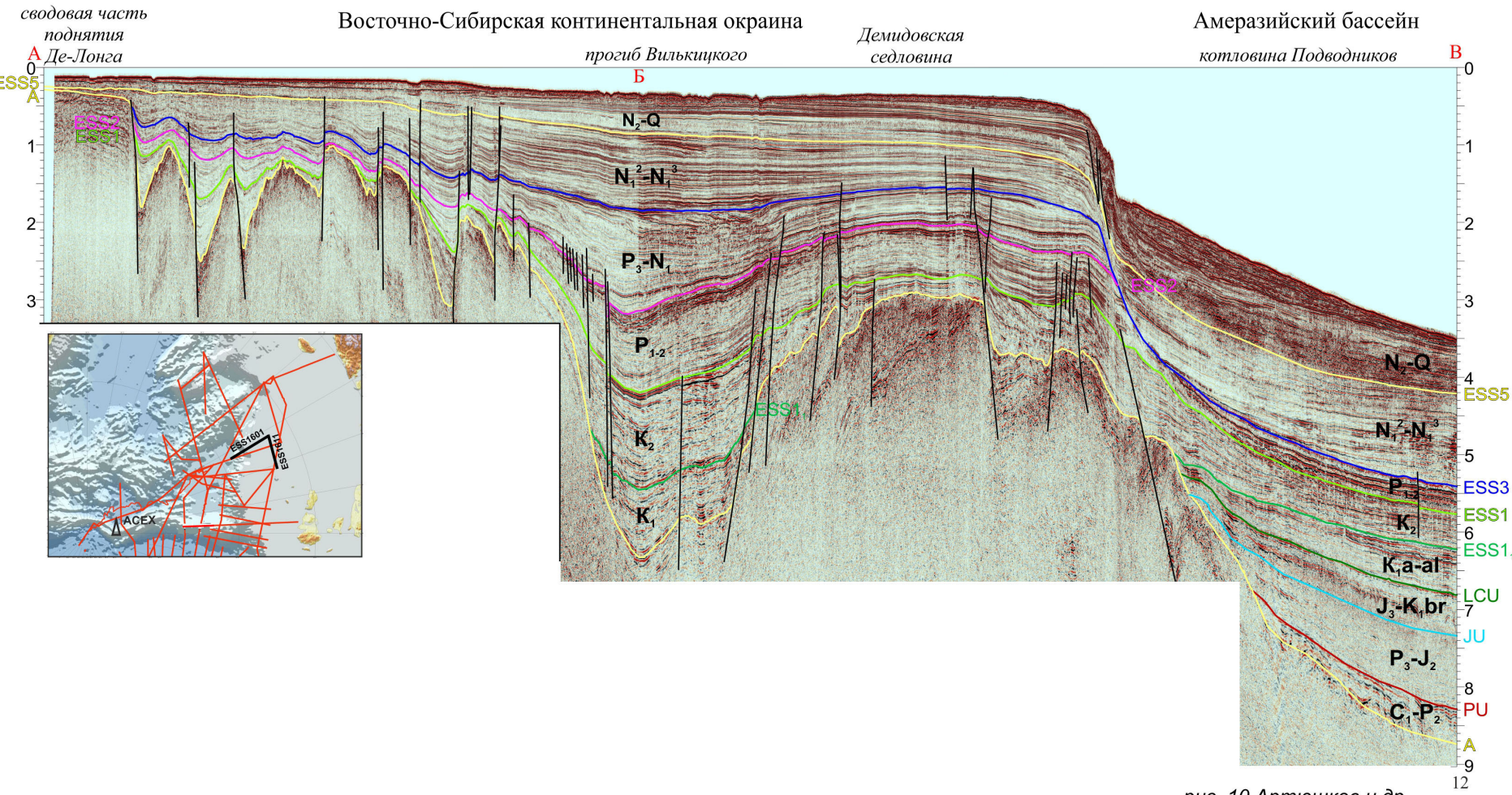

рис. 10 Артюшков и др. 